\title{
Cooperative Learning Strategy through Dancing Extracurricular as an Effort to Establish Hard Work and Patriotism Characters for Students at Primary School
}

\author{
Okto Wijayanti \\ Primary School Teacher Training Education \\ FKIP Muhammadiyah University Purwokerto \\ wijayantiokto@gmail.com
}

\begin{abstract}
This study aimed to describe cooperative learning strategies as an effort to establish the character of hard work and patriotismthrough dancing extracurricular activities. Participants in this study consisted of dance trainer and students. Observation, interviews, and documentationwere conducted to collect the data. Descriptive qualitative was used to analyze the data. The results of the study were: 1) the teacher applied character education ofhard work and patriotismthrough extracurricular activities of dance in which Banyumasan dialect to help students in understanding the message of dance movements. 2) The teacher established a sense of love and pride in the native culture of Indonesia, especially the Banyumas culture, so that students demonstrated the ability to dance Banyumas dance proudly, 3) the students' hard work while learning the dance improved a sense of pride in studying the national and local culture of Banyumas. Implementation of cooperative learning strategies character in dance extracurricular activities were divided into 6 stages, namely conveying goals and motivation, presenting information, organizing students in groups, guiding work groups, giving evaluation, and awarding.
\end{abstract}

Keywords: character of cooperation, patriotism, students, dance extracurricular activities.

\section{INTRODUCTION}

Extracurricular activities are intended to develop students' personalities, talents, and abilities in various fields out of academics. Wibowo (2013: 15) stated "the implementation of character education can be done in schools integrated in learning and self-development through extracurricular activities, and integration in school management". One of them is dance extracurricular activities which are expected to nurture students in their dancing skills and to educate their characters so that later they can have a patriotism to the culture. Besides, extracurricular activities of dance are not only facilitate participants' hobbies, interests and talents of the learners but it can also hone and improve emotional intelligence in processing feelings and thoughts. The modern dance, one of the available foreign cultures and easy to learn with many devotees, is often published through electronic media so it $t$ makes it so easy to learn. Unlike the local culture (Indonesia) which is unique and has noble values, many assume that culture itself is difficult to understand and learn because foreign culture is easier to imitate and to learn. The uniqueness in the noble values of culture relating to morality, character, and good character of the nation should be learned by students, including the character of hard work and patriotism. The character of hard work is associated with patriotism because these both characters are needed in order to realize patriotism, either love in the form of pleasure or pride. The dance learning activities was conducted through extracurricular activities at school

Extracurricular activity at school conducted as an effort to establish a sense of love for local culture is Banyumas dance. Establishing the character of patriotismin schools cannot be separated from the role of the trainer as well as the teacher in choosing specific strategies for carrying out dancing 
extracurricular activities. It becomes the priority to find out the good obtained through the noble values of the nation's culture, to love goodness by loving the homeland, nation, and culture more as well as to do the good through customizing good attitudes in learning dance. This was stated by Lickona who said that character education includes three main elements, namely knowing the good, desiring the good, and doing good.

In the implementation of extracurricular activity inprimary schools of Banyumas Regency, studentsobtain guidance and direction on dance extracurricular activities so that students are able to establish a sense of patriotism and hard work in learning culture. In practice, cooperative learning strategies was implemented to make the students good at dancing, and the most important thing is to naturally establish the character of hard work through the best dance performances both individual and in groups, and to establish character of patriotismthrough students' understanding of absorbing national cultural values through dance.

\section{LITERATURE REVIEW}

The procedure for implementing dance cooperative learning was carried out in 6 stages, namely conveying goals and motivation, explaining the material by providing information, organizing students in study groups, guiding the group to work, evaluating, and assessing achievement.

Three main elements in character education according to Lickona are, knowing good, desiring the good, and doing good. Character education promoted in elementary school learning in the curriculum2013 signifies the importance of attitudes and behavior of students in participating in teaching and learning activities in the classroom. Intellectual and psychomotor abilities of students must be supported with students' ability to manage their attitude, especially affective ability in this case. Wibowo (2012: 6) explains "character education is the education of noble values derived from the culture of the Indonesian nation itself in order to nurture the personality of the young generation".
In line with Wibowo, Samani \& Hariyanto (2012: 44) say "character education is the process of providing guidance to students to become fully human beings with a character in the dimensions of heart, mind, body, feeling, and intention".

Patriotism or nationalism emphasizeon collective identity. Someone within the scope of a large group must be able to express their own culture, this identity will be appear if we go abroad, starting from skin color, body posture, language, religion, and culture. The sense of nationalismnurtured in elementary schools is more highlighted to homeland which is rich country in various cultures, one of which is Banyumas culture. Loving cultures in the form of Banyumas dance can be trained through learning culture in a fun way, with the character of hard work, patriotism, and togetherness.

Extracurricular activities are additional activities outside the structured program and regular school hours and are expected to enrich and deepen the students' knowledge and abilities. The dance extracurricular activitieswere carried out in elementary schools in curriculum 2013 based on school policies and needs.

Dance as an art form is a special activity, not merelyabout expressing emotional movement and expressing feelings in motion without direction and purpose. The presence of dance starts from stimuli affecting human nerves organs. Sekarningsih \& Heny (2006: 4) suggest that dance is an expression of human feelings by movements of the human body. The function of dance art education is important to learn related to character, as stated by Hidajat (2005: 7) in detail classifying "the function of dance education in 8 domains." Some domains are related to the nurturing character of discipline and patriotism namely the art of dance as a medium to foster personality, to identify characteristics, andto understand cultural values.

\section{METHODS}

The method used in this study was a qualitative descriptive research method. Sugiyono said that qualitative research was consideredas a naturalistic research method 
because this research was carried out in natural conditions so it was not only an explanation by words,quotations derived from researcher'sdocuments, such as interviews, and documentation. Research participants were teacher and students. This qualitative descriptive study focuses onidentifying things related to cooperative learning strategies in the implementation of dance extracurricular activities in order to establish the character of patriotism on national culture.

Data were collected by interviews, observation, and documentation with participants in depth. Interviews and observations were used to collect the data. Data analysis method selected qualitative data analysis according to Miles and Huberman namely data reduction, data display, and conclusion. Triangulation was done with three data collection techniques, namely interviews, observation, and documentation. All the techniques are interrelated to each other.

\section{RESULTS AND DISCUSSION}

Cooperative learning strategies were expected that students not only good at dancing, but also to rise the character of hard work naturally through the best dance performance either individually or in groups. Besides, it was expected to establish the character of patriotism through students' understanding of the nation's cultural values nationally through learning dance.Lickona conveyed 3 basic elements in education namely, knowing the good, desiring the good, and doing the good. Three basic elements in character education are derived from the absorption of national cultural values through learning dance.

Nurturing the character of patriotism for students in dance learning was conducted by: first, the teacher used his own regional dialect in carrying out extracurricular dance learning to students, for exampleNgapak Banyumas language in learning. The use of the Banyumasdialect during extracurricular learning could be one of the strategies in applying the character of patriotism to culture. Second, the teacher explained the movements in dance to help students understand the message available when dancing. Dancing had a combination of motion and song, so students were expected to be able to express various emotions and behavior. Wibowo (2012: 6) explained "character education is the education of noble values derived from the culture of the Indonesian nation itself in order to foster the personality of the young generation". The formation of students' personality as a young generation was strengthened by Samani (2012: 44), he mentioned "character education is the process of giving guidance to students to become a fully human being with a character in the dimensions of heart, mind, body, feeling, and intention".

Suyadi said that the cooperative learning strategy with characters was arranged in 6 stages. Development of cooperative learning strategies with character through dance learning in extracurricular activities. Stage 1. Teachers established a sense of love and pride to the students towards indigenous Indonesian culture. The teacher conveyed the purpose of learning by having discussion on the development of dance so that students could respond wisely to the modern and Western dance in daily life. The main learning was the teacher invited students to foster a sense of love the culture of the Indonesian nation, especially traditional dance.

Stage 2. The teacher provided material supporting the dance learning in a discussion. The teacher taught the dance by introducing their dance types, introducing traditional information in other areas, introducing the movements in their dance, conveying the function of dance education, finally, and guided practice. The success of teacher in teaching dance could be seen from the level of students' enthusiasm, discipline, and diligence in participating in dancing extracurricular activities until the end of the semester. The teacher gave the studentsan opportunity to show their skills after the training in dance extracurricular lesson. These activities could be carried out in several activities in school (evaluation of activities, dance examinations, school farewell party) or outside school (National Student Art Contest Festival).

Stage 3. In every activity and evaluation of dance extracurricular activities, the trainer divided learners into small groups. Each group 
consisted of four students. The trainer applied the group learning in order to see changes in their attitude and process of learning, therefore, it was easier to communicate with their friends, especiallywith less proficient in training, they could certainly learn together. The character of cooperation and mutual respect were built through the heterogeneous distribution of small groups. Working together in groups brings the same goals so that they have responsibility for the work of the group members.

Stage 4 . The teacher provided information (from printed materials or electronic sources) about Banyumas culture. Teachers and school provided books which could support dance extracurricular activities, as a reading material for students to broaden their knowledge of art. Art-related reading books were used in learning every day because the school implemented thematic learning which was discussed in SBdp subject in the classroom.

Stage 5. The teacher evaluated the learning outcomes of the material that had been studied. It was done by having presentation in each group, the teacher also evaluated the work process of the hard work, patriotism, cooperation, tolerance, discipline, responsibility, and honesty characters of each student in the group. The focuses of evaluation in learning were the character of students' hard work and patriotism. The teacher became a role model in deliveringlearning material. The teacher gave an example of the dancing practice in front of students with sincerity, pride, and patriotism so that it could be a role model for all students.

Stage 6. The teacher gave awards. The awards could be in the form of good score, praise, and the opportunity to perform at the events which had been scheduled at school.

\section{CONCLUSIONSAND SUGGESTIONS}

The implementation of Cooperative learning strategies with character content in dance extracurricular activities on the explanation and motivation focused on establishing the characters to hard work and patriotism. 2) Learning in groups was aimed atforming team collaboration and harmony, 3) Individual and group assessmentwere in the form of dance performance in extracurricular activities. The teacher implemented character education of hard work and patriotism by explaining it inBanyumas Dialect, so that it helped students understand the message or the meaning of dance movements. 4) The teacherestablished a sense of love and pride in Indonesian indigenous culture, especially Banyumas culture, so students would proudly demonstrate the skills to perform Banyumas dance, 5) Students' hard work during learning or training outside regular lesson raised the pride of students as an effort to learn thelocal culture of Banyumas, by performing the dance at their best in a good harmony through the integration of the attitude of cooperation, tolerance and mutual respect among one another. Therefore, it could foster the character of hard work in performing dance choreography in groups.

\section{REFERENCES}

Hidajat, Robby. (2005). Wawasan Seni Tari.Malang: Jurusan Seni dan Desain.

Lickona Thomas. (2014). Pendidikan Karakter. Bandung : Nusa Media.

Moleong.(2011). Menjadi Guru Profesional: Menciptakan Pembelajaran Kreatif

Rosdakarya. dan Menyenangkan. Bandung:

Moleong, Lexy. (2013). Metode Penelitian Kualitatif. Bandung: Rosda Karya.

Sagala, Syaiful. (2011). Kemampuan Profesional Guru dan Tenaga Kependidikan. Alfabeta: Bandung.

Samani, Muchlas \& Hariyanto. (2011). Konsep dan Model Pendidikan Karakter. Bandung: Remaja Rosdakarya.

Sekarningsih, Frahma \& Heny Rohayani. (2006). Kajian Lanjutan Pembelajaran Tari dan Drama I. Bandung: UPI PRESS. 
Sugiyono. (2010). Metode Penelitian Pendidikan Pendekatan Kuantitatif, Kualitatif dan $R$ \& $D$. Bandung : Alfa Beta.

Sugiyono. (2013). Metodologi Penelitian Pendidikan. Bandung: Alfabeta.

Suyadi. (2013). Strategi Pembelajaran

Pendidikan Karakter. Bandung:

Rosdakarya.
Wibowo, Agus. (2012). Pendidikan Karakter Strategi Membangun Karakter Bangsa. Pustaka pelajar.

- Berperadaban. (2013). Manajemen Pendidikan Karakter di Sekolah. Yogyakarta: Pustaka Pelajar. 